NATURAL MOLDING SANDS

OF IOWA

by

JOHN E. SMITH 



\section{CONTENTS}

INTRODUCTORY -

TESTS ON Foundry SAND_...

Permeability ---_- 457

Description of Iowa Molding Sands

Benton county -._._.

Black Hawk county -_..-_. 458

Boone county -.-_-

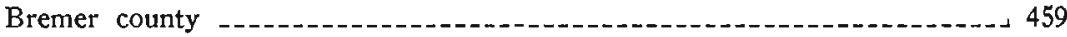

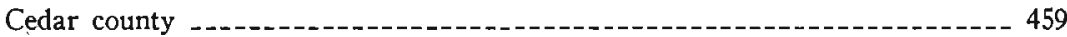

Clayton county _...

Clinton county -._.

Dallas county - .

Des Moines county" -

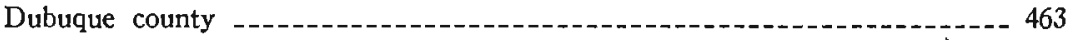

Floyd county -........ 463

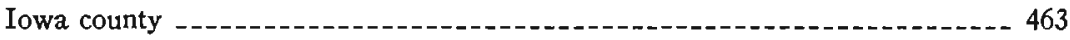

Jasper county -..--_.

Johnson county -._-_. 464

Lee county _...

Linn county -.-...- 466

Louisa county -

Marshall county -.-_- 469

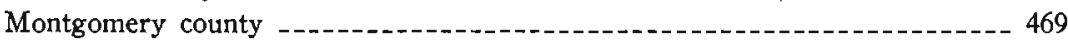

Muscatine county -._-_-_-_-_-_._- 470

Polk county -.....

Scott county -...-.--

Tama county -

Wapello county -...- 474

GEOLOGY OF FOUNDRY SANDS_._.

REASONS FOR IMPORTATIONS

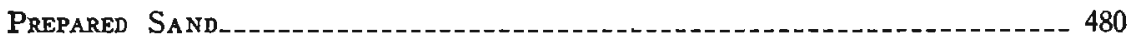

Summary and Conclusions._-_._.

Consumers of Molding SAnd_._-_. 481

SoUrCES of Foundry SANd USEd In IoWA 
69. Lufkin pit, Reasnor_........ 464

70. Roadside bank north of Iowa City

71. Eolian sand near Tiffin

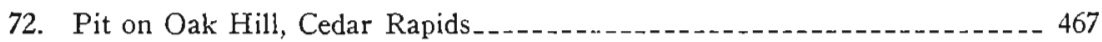

73. Sketch map of Cedar Rapids and vicinity

74. Pit at Muscatine

75. Harris pit at Des Moines

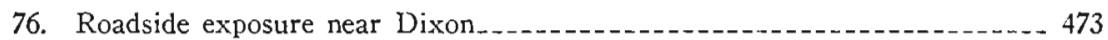

77. Map showing pits producing molding sand

78. Franklin pit, Ottumwa_..._-_-_- 475

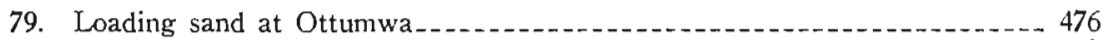




\title{
NATURAL MOLDING SANDS OF IOWA
}

\author{
Introduction
}

Natural molding sand is a mixture of sand, silt and clay in such proportions as to make it adapted for use in various kinds of foundry work. Commonly the amount of clay varies from about five to nearly thirty per cent.

The amount of material of each size for the samples analyzed is shown in the table on page 460 . The figures given in the column designated "On 100", for example, indicate the percentages of the respective totals that remained on the screen having 100 meshes to the linear inch when the test was made. The same is true in each column having a similar heading.

\section{Tests on Foundry Sand}

All tests given in the table on page 460 were made in accordance with the methods set forth by the Joint Committee on Molding Sand Research (see American Foundrymen's Assn. bulletin, June 1, 1924, edition corrected Aug. 1, 1924). This work was conducted by Dr. H. Ries of Cornell University, Ithaca, New York.

Permeability.-The gases that are formed when molten metal is poured into the mold, such as steam and expanding air, must have an easy means of escape through the sand in such a way as not to disturb the position of the sand while the pouring and cooling are in progress. By means of the standard test used permeability is determined as the volume of air per minute, per gram per square centimeter pressure, per unit volume in the specimen.

Permeability is best when the various size grains of the molding sand are evenly distributed throughout the mixture. If the sand grains are too evenly covered with clay permeability may be low or poor. A small amount of very fine material obstructs the easy passage of the gases through the sand. The clay, like other textures, should be evenly distributed throughout the mass.

The best results in tests of bond strength seem to be obtained when the water content is between four and six per cent. The bonding strength is given in grams of actual weight of the average breaking 
strength of a bar of molding sand made under standard conditions. (See American Foundrymen's Assn. bulletin, June 1, 1924, also bulletin 50, Illinois Geol. Survey, by M. S. Littlefield.)

\section{Description of Iowa Molding Sands}

Benton County.-One exposure of good molding sand adapted for use in bench work and in other light work was found one mile east and one and three-fourths miles south of Garrison (the nearest railway station), where about ten feet of coarse-grained loess underlies some five feet of cover in a roadside cut.

North of Shellsburg, two and one-half miles, near the middle of the east half of the northeast quarter of section 34, Township 85 North, Range 9 West, in a cut on the east side of the highway, is located a deposit of molding sand about ten feet thick. Though suited to use in gray iron work, this material for the most part lies under heavy cover and has no commercial value at present. Apparently it is glacio-fluvial material formed as outwash at the margin of the ice during a recessional stage of the Iowan glaciers.

Black Hawk County.-In several places in and near Waterloo molding sand has been produced but no areas of it are being worked at present. Most, if not all, of this seems to have had an eolian origin.

Alluvial sand and "bank sand" or that found in areas of glacial outwash east of the river have yielded core sand in this vicinity. Some of this sand has been reworked by the wind.

Along the bluffs nearly a mile west of La Porte City both east and west of the old quarry a layer of good molding sand, one to three feet thick, rests on glacial till and is covered with a zone of soil two to three feet thick. This area of molding sand is probably not very extensive and is doubtless of eolian origin. It is suitable for use in bench and light floor work.

Boone County.-One location yielding a sample of what seems to be an excellent molding sand was found in Boone county. It occurs in a roadside bank where the road leaves a river terrace on the right side of the Des Moines river valley and is about 20 feet above the flood plain. This location is about three miles west of Madrid in the southwest quarter of the northwest quarter of section 27, Township 82 North, Range 26 West. It lies beneath an overburden of nearly ten feet and is, therefore, of doubtful commercial value. Only field tests 
were made on this sand. It is a river terrace deposit and was formed as alluvium at a time when the surface of the river water was much higher than at present.

Bremer County.--One mile north of Waverly in the southwest quarter of the southeast quarter of section 26, Township 92 North, Range 14 West, good molding sand was found in several places. Toward the northwestern or windward ends of the eolian hills in this part of the county molding sand may be found in numerous localities. Such deposits range in thickness from a few inches to four feet and are limited in extent to patches varying in size from a few square rods to half an acre. No sand from here has been used but the deposit has a possibility as a short-lived field.

Cedar County.-No molding sand is produced in this county but a good quality of material is found in several places in road cuts along Lincoln Highway west of Stanwood and west of Mechanicsville. These illustrate well the eolian type of origin and consist of alternating bands of sand and clay up to one inch thick. In a few of these outcrops good molding sand can be found in layers up to five feet thick. There is, however, little hope for commerciąl development because of the irregularity in thickness and extent of the deposits.

A Typical Section Feet

1. Soil and subsoil ................................... 4

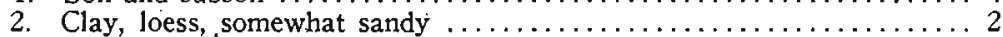

3. Clay, loess, and sand, many alternating layers, less than one inch thick, mostly good molding sand $\ldots \ldots \ldots \ldots \ldots \ldots \ldots \ldots \ldots \ldots, \ldots \ldots \ldots$

IDENTIFICATION OF THE SANDS IN TABLE OF TEST RESULTS

Number 1. A core sand from the Prier pit at Marshalltown. See page 469 also. 2. A molding sand from the Williams pit four miles east of Marshalltown, location and description given on page 469 . 3. See page 463 for location of the place from which sample number three, a molding sand, was obtained near Floyd Station in Floyd county.

4. A molding sand from pit at Nora Springs, . Floyd county, operated by the HartParr Company. See page 463. 5. Molding sand from the Chinn pit on Harrison Road at Clinton. See also page 462. 6. A molding sand from the Vosburg pit at Clinton. See page 462. 7. A molding sand from Oak Hill, Cedar Rapids. See page 468. 8. See page 471 for details concerning the molding sand from the Harris pit at Des Moines.

9. A molding sand from the Ben Lufkin pit at Reasnor, Jasper county. See page 464 and figure 69. 10. Core sand from the Franklin pit at Ottumwa. See page 475 and figures 78 and 79 . 11. Molding sand from Muscatine. See page 470 and figure 74. 12. Molding sand from Johnson county about four miles north of Iowa City. See page 464 and figure 70.

13. Molding sand from Dallas City, Illinois. 14. Molding sand from Milan, Illinois. 15. Molding sand, "No. 1", from Albany, New York (The analyses of numbers 13,14 and 15 are taken from bulletin number 50, Illinois Geological Survey, by M. S. Littlefield). 
Tesis of Lozva Molding Sands

\begin{tabular}{|c|c|c|c|c|c|c|c|c|c|c|c|c|c|}
\hline No. & $\begin{array}{l}\text { On } \\
20\end{array}$ & $\begin{array}{l}\text { On } \\
40\end{array}$ & $\begin{array}{l}\text { On } \\
70\end{array}$ & $\begin{array}{l}\text { On } \\
100\end{array}$ & $\begin{array}{l}\text { On } \\
140\end{array}$ & $\begin{array}{l}\text { On } \\
200\end{array}$ & $\begin{array}{l}\text { On } \\
270\end{array}$ & $\begin{array}{c}\text { Through } \\
270\end{array}$ & $\begin{array}{l}\text { Clay } \\
\text { Subs. }\end{array}$ & Total & $\begin{array}{c}\text { Water } \\
\text { per cent }\end{array}$ & $\begin{array}{l}\text { Bondl } \\
\text { Str. }\end{array}$ & Perm. \\
\hline 1 & .30 & 1.02 & 1.38 & 1.54 & 1.28 & 1.48 & 6.9 & 45,7 & 39.76 & 99.36 & $\begin{array}{r}4.7 \\
5.8 \\
6.7 \\
8.5 \\
10.5 \\
12.5 \\
13.7\end{array}$ & $\begin{array}{l}326 \\
336 \\
290 \\
273\end{array}$ & $\begin{array}{l}1.4 \\
4.2 \\
4.4 \\
4.4 \\
7 . \\
7.7 \\
7.7\end{array}$ \\
\hline 2 & & 1.92 & 57.8 & 27.9 & 7.34 & 1.34 & .34 & 1 & 2.82 & 99.56 & $\begin{array}{r}2 . \\
-2.4 \\
3.5 \\
5.7\end{array}$ & $\begin{array}{r}121 \\
100 \\
88 \\
85\end{array}$ & $\begin{array}{l}185 \\
178 \\
167 \\
156 .\end{array}$ \\
\hline 3 & & .78 & 4.24 & 1.8 & 1.48 & 1.72 & 11.34 & 54.38 & 24. & 99.74 & $\begin{array}{r}4.7 \\
6.6 \\
8.2 \\
9.7 \\
12.6\end{array}$ & $\begin{array}{l}268 \\
257\end{array}$ & $\begin{array}{l}3.1 \\
3.5 \\
4.4 \\
9.4 \\
7.7\end{array}$ \\
\hline 4 & .5 & 9.34 & 29 . & 12.88 & 5.34 & 4.68 & 7.24 & 13.34 & 17.02 & 99.34 & $\begin{array}{l}3.2 \\
4.4 \\
6.3 \\
8.3\end{array}$ & $\begin{array}{l}240 \\
298 \\
290 \\
275\end{array}$ & $\begin{array}{l}40 \\
50 \\
49 \\
42\end{array}$ \\
\hline 5 & & .94 & 8.08 & 31.9 & 15.88 & 10.1 & 12.28 & 12.46 & 7.76 & 99.4 & $\begin{array}{l}5.9 \\
7.6 \\
9.6\end{array}$ & $\begin{array}{l}131 \\
140 \\
131\end{array}$ & $\begin{array}{l}17.8 \\
19.5 \\
15.7\end{array}$ \\
\hline 6 & & .24 & 4.78 & 13.38 & 9.84 & 20.3 & 19.2 & 23.14 & 8.26 & 99.14 & $\begin{array}{l}4.5 \\
5.3 \\
8 .\end{array}$ & $\begin{array}{l}160 \\
142 \\
140\end{array}$ & $\begin{array}{l}27 . \\
25.8 \\
24.2\end{array}$ \\
\hline
\end{tabular}




\begin{tabular}{|c|c|c|c|c|c|c|c|c|c|c|c|c|c|}
\hline 7 & & .48 & 6.28 & 7.64 & 6.78 & 5.5 & 13.8 & 39.14 & 20.1 & 99.72 & $\begin{array}{l}3.3 \\
3.9 \\
6 . \\
8.1\end{array}$ & $\begin{array}{l}248 \\
229 \\
197 \\
178\end{array}$ & $\begin{array}{l}8.2 \\
9 . \\
8.5 \\
7.9\end{array}$ \\
\hline 8 & & .26 & 6. & 14.06 & 15. & 13.44 & 18.8 & 18.98 & 12.64 & 99.18 & $\begin{array}{r}4.3 . \\
6.3 \\
8.4 \\
10.3\end{array}$ & $\begin{array}{r}247 \\
230 \\
\end{array}$ & $\begin{array}{r}9 . \\
13 . \\
21.8 \\
17.3\end{array}$ \\
\hline 9 & & Tr. & .68 & 1.98 & 3.44 & 5.74 & 15.24 & 57.2 & 17. & 99.28 & $\begin{array}{r}5.8 \\
8.1 \\
9.9 \\
12.2\end{array}$ & $\begin{array}{l}150 \\
182 \\
186 \\
184\end{array}$ & $\begin{array}{l}7 . \\
8.5 \\
7.5 \\
6.5\end{array}$ \\
\hline 10 & .26 & 10.06 & 59.2 & 11.5 & 1.34 & .8 & .94 & 2.36 & 13.3 & 99.76 & $\begin{array}{l}4.2 \\
6.4 \\
8.8\end{array}$ & $\begin{array}{l}345 \\
375 \\
290\end{array}$ & $\begin{array}{l}193 . \\
219 . \\
126 .\end{array}$ \\
\hline 11 & $\mathrm{Tr}$ & .74 & 19.74 & 14.64 & 6.64 & 3.04 & 7.64 & 25.6 & 22.06 & 100.1 & $\begin{array}{l}3 . \\
4.1 \\
6.2 \\
8.2\end{array}$ & $\begin{array}{l}256 \\
219 \\
213\end{array}$ & $\begin{array}{l}6 . \\
8.2 \\
7.7 \\
7 .\end{array}$ \\
\hline 12 & Tr. & 2.9 & 31.54 & 16.34 & 6.9 & 3.48 & 2.98 & 12.88 & 22.26 & 99.28 & $\begin{array}{r}3 \\
4.1 \\
6.1 \\
7.9 \\
10 . \\
11.5\end{array}$ & $\begin{array}{l}265 \\
262 \\
251\end{array}$ & $\begin{array}{c}12.6 \\
19 \\
33 \\
40 \\
1.1\end{array}$ \\
\hline 13 & .4 & 2. & 18.7 & 12.1 & 9.3 & 13. & 5. & 29.1 & 9.4 & 99 . & $\begin{array}{l}4 . \\
6 . \\
8 .\end{array}$ & $\begin{array}{l}181.5 \\
197.8 \\
173.8\end{array}$ & $\begin{array}{l}13.2 \\
13 . \\
12.6\end{array}$ \\
\hline 14 & & 1.2 & 9.8 & 7.1 & 7.4 & 11.8 & 19.8 & 33.8 & 8.2 & 99.1 & $\begin{array}{l}4 . \\
6 . \\
8 .\end{array}$ & $\begin{array}{l}236.4 \\
271.4 \\
261.8\end{array}$ & $\begin{array}{l}4.4 \\
4.6 \\
4.7\end{array}$ \\
\hline 15 & & .2 & 1.3 & 2.9 & 9.5 & 29 . & 15.9 & 34.4 & 5.9 & 99.1 & $\begin{array}{l}4 . \\
6 . \\
8 .\end{array}$ & $\begin{array}{l}140.3 \\
144.2 \\
146.0\end{array}$ & $\begin{array}{l}15.5 \\
13.7 \\
14.2\end{array}$ \\
\hline
\end{tabular}


Clayton County.-A high grade silica sand is quarried from an outcrop of St. Peter sandstone at Clayton. This is a clean white sand testing 98 per cent to 99 per cent $\mathrm{SiO}$. It is the geological equivalent of the well-known silica sand produced at Ottawa, Illinois. It is used in cast steel molding at Waterloo.

Clinton County.-The pit from which sample number 5 was taken is located on Harrison Road about two blocks from Lincoln Highway and three to four blocks from rail spur at the plant of the Collis Manufacturing Company. The pit is owned by F. A. Chinn, and is a part of several acres in the southwest quarter of the southwest quarter of section 14, Township 81 North, Range 6 East.

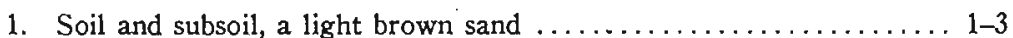

2. Sand, molding. Shows dune structure in alternation of layers from one to five inches thick and containing less clay than other strata which have a similar thickness, which makes them stand out in relief as the face weathers.

Sample number 6 was taken from the P. E. Vosburg pit located near the crest of the hill on Tenth Street.

Section of the Vosburg Pit

1. Soil

Sech.................................. 3

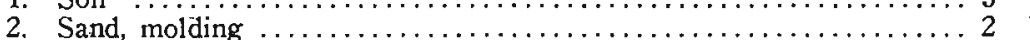

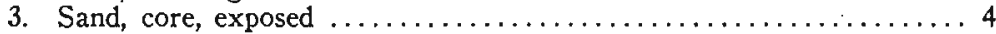

Along the slope of the hill on the south side of Harrison Road there are many small areas in which good molding sand pits could be opened. A test was made in a bank on Fourteenth Street one block from Harrison Road and an excellent quality of molding sand was found.

Dallas County.-About three miles east of Redfield in the northeast corner of section 2, Township 78 North, Range 29 West, the highway cuts through an area of sandy deposits near the margin of the Wisconsin glacial drift. The field tests indicate that some of this material is good molding sand and since it is located within half a mile of the Chicago, Milwaukee, St. Paul and Pacific railroad it may some time have a shipping value. An exposure of approximately 15 feet exists here under five to six feet of glacial till.

Des Moines County.-A few areas containing molding sand were found on the low river terraces in the region south of Burlington. Some of these areas are along the highway near the Burlington track in the east half of section 35, (Union) Township 69 North, Range 3 
West. This is partly a coarse, heavy, red sand suitable for use in medium to heavy castings but several grades for use in lighter work also are found here.

Dubuque County.-No molding sand is produced in Dubuque county. Most of the sand used here is brought from the bluffs just across the river. On the Iowa side some loess is found but most of it is too fine for any use as molding sand.

Floyd County.-Sample number 3 was taken from the roadside pit on the farm of F. O. Martin, 300 yards from the railroad station in the southeast quarter of the southeast quarter of section 9, Township 96 North, Range 16 West. This is an eolian ridge extending for some distance in an east-west direction on both sides of the road. The sample was taken from numbers three and four of the section below. It is reported that some sand has been shipped from this pit.

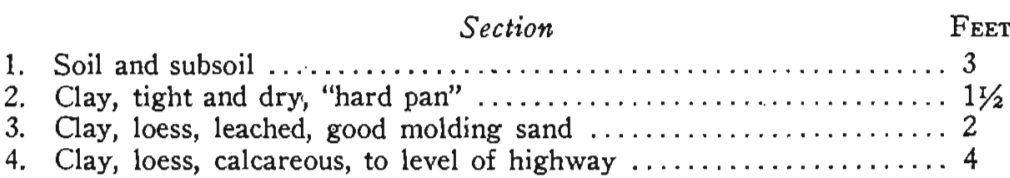

Sample number 4 was collected in the northwest quarter of the northeast quarter of section 18, Township 96 North, Range 18 West. This property is in charge of the Hart-Parr Company and the sand is used in their plant at Charles City. Sample was taken from numbers 2, 3 and 4 of the section.

1. Soil and subsoil, brown, oxidized and leached $\ldots \ldots \ldots \ldots \ldots \ldots \ldots 2$

2. Clay, arenaceous, good molding sand, leached ................. 1

3. Clay, arenaceous, first class molding sand, leached $\ldots \ldots \ldots \ldots \ldots \ldots 1$

4. Sand, containing three two-inch streaks, with much clay, leached; to bottom of pit ..........................................

Several other areas in the county contain molding sand. Probably those having the largest extent are in Scott township several miles west of Marble Rock.

Iowa County.-Several areas along the south side of the Iowa river valley in this county contain good molding sand but no exploiting has been done. A typical location and section is found in the highway cuts between the northern parts of sections 3 and 4, Township 80 North, Range 10 West. 


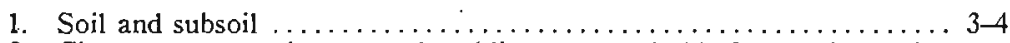

2. Clay, arenaceous, loess, good molding sand, suitable for use in casting aluminum, brass and other light work $\ldots \ldots \ldots \ldots \ldots \ldots \ldots \ldots . \ldots \ldots$

Jasper County.-In Jasper county the principal producing locality is near the city of Reasnor on the property of Mr. Ben Lufkin. The pit is in the southwest quarter of the northeast quarter of section 11 ,

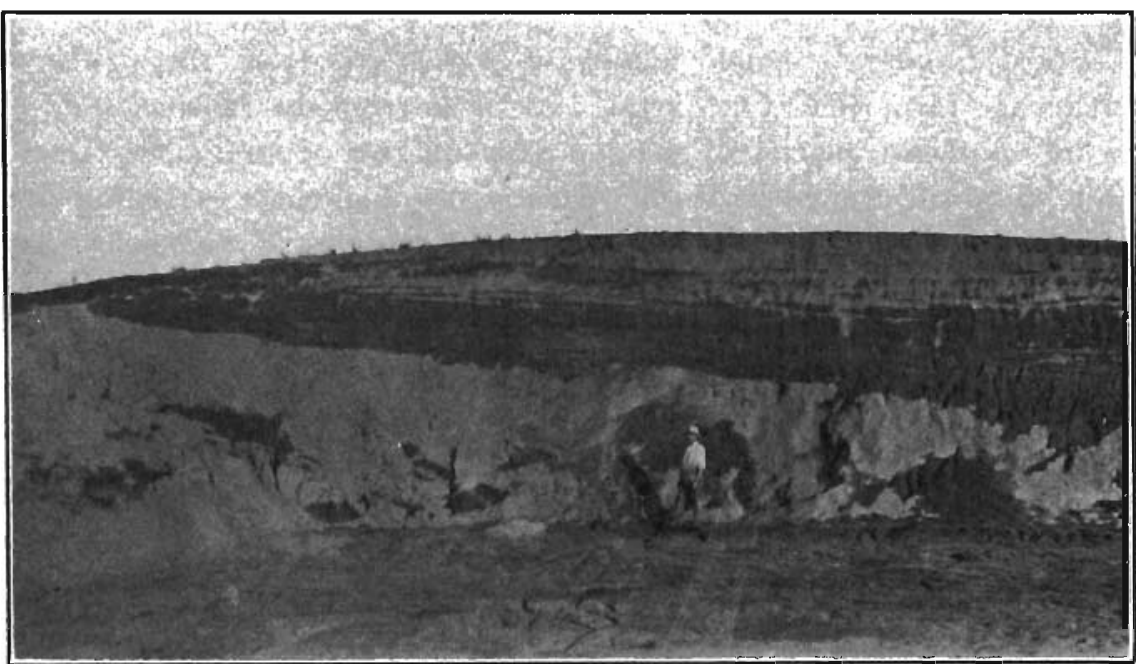

Fig. 69.-A view taken in the pit owned by Mr. Ben Lufkin at Reasnor, Jasper county. See below for description of the layers of molding sand from which sample number nine was obtained.

Township 78 North, Range 19 West. It is cut in an eolian ridge extending in a northwest-southeast direction, a section of which is as follows :

Section $\quad$ FEET

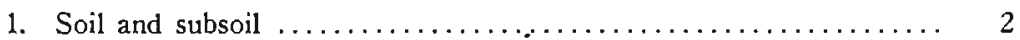

2. Molding sand, suitable for light bench work, used in molding alumi-

num work at Newton, Davenport, etc. ................... $6-8$

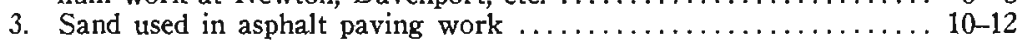

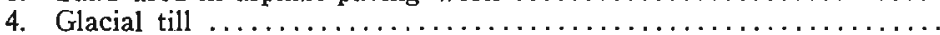

This locality lies within a mile from the railway station, and its elevation is high enough so that the haul is down grade most of the way.

Johnson County.-Sample number 12 was collected from a roadside cut on the Red•Ball highway in the northwest quarter of the southwest quarter of section 21, (Penn) Township 80 North, Range 6 West. The material was taken from number 2 of the section given below. 


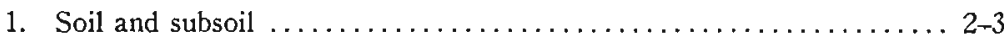

2. Sand, argillaceous, reddish brown, a molding sand with good bond,

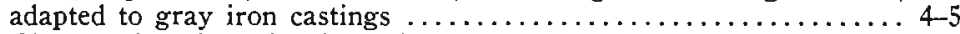

3. Clay, sandy, with a few irregular layers of molding sand 4 to 6 inches thick, exposed $\ldots \ldots \ldots \ldots \ldots \ldots \ldots \ldots \ldots \ldots \ldots \ldots \ldots \ldots \ldots, 4$

This is eolian in origin and is located about half a mile from the margin of the Johnson county lobe of the Iowan ice as shown on the maps. (See fig. 70 and table, p. 460.)

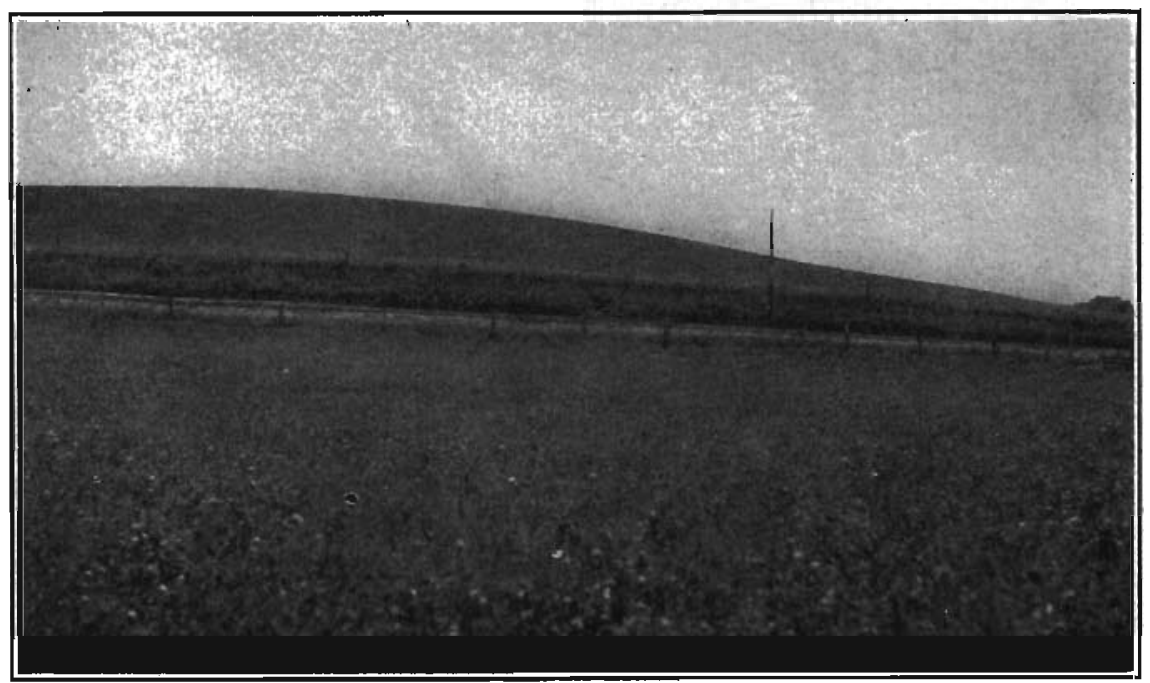

Fig. 70.- Sample number 12 was obtained from the uphill roadside bank near the middle of this picture. Johnson county, see page 464 .

A good exposure is found in a road cut west of Tiffin in the southwest quarter of the northwest quarter of section 29 near the cemetery. The eolian character of the deposit is seen in figure 71 .

Section West of Tiffin FEET

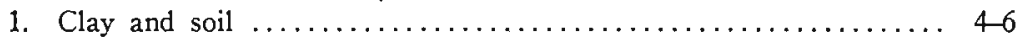

2. Clay, sandy, molding sand for light to medium work (lens shape) .. $0-10$

One of the thickest deposits of molding sand in the state and one well located for shipping (50 yards from track, one-fourth mile from station) is found on the Jos. Ray estate at Midriver in the southeast quarter of the southeast quarter of section 27, Township 81 North, Range 7 West.

1. Soil and subsoil

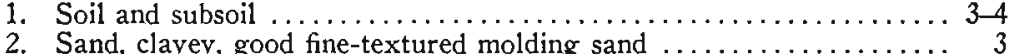




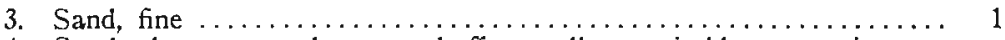

4. Sand, clayey, noncalcareous, buff to yellow, suitable to use in gray

iron and brass work; to level of highway ................ 25

Several other deposits of minor importance were found in the county.

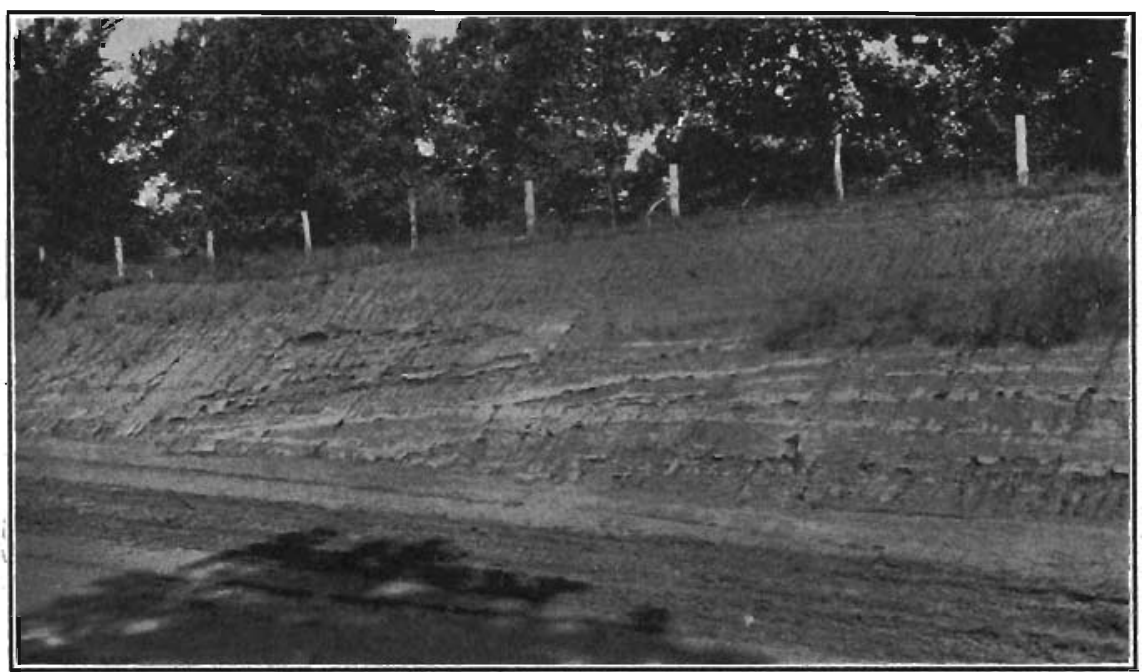

Frg. 71.-The material seen in this cut was blown by the wind from the left, northwest. The hill has been built up by successive additions, several of which can be seen overlapping those below. Rows of concretions are seen near the right margin. This cut is in Johnson county, west of Tiffin, as described on page 465 .

Lee County.-One locality having a grade of molding sand in quantity and quality indicating some degree of commercial promise is found in a ridge crossing the east-west highway in the middle of the eastern half of section 15, Township 67 North, Range 5 West. This is a deposit of river terrace sand worked over and developed as a ridge by the wind. This is within five miles of Fort Madison and less than a mile from the Santa Fe railway. It is a grade of sand adapted to use in gray iron work.

Linn County. - Two deposits of coarse red sand used as core sand and as molding sand for heavy castings were found in Linn county. One near Covington is on the east and south sides of the highways at the crossroads about one mile south of the Milwaukee railway station, in the east half of section 15 , Township 83 North, Range 8 West, on the farm of F. M. Davis.

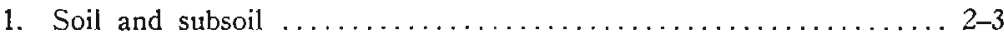

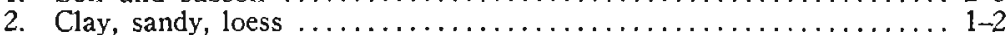

3. Sand, clayey, a molding sand with good bond, adapted for use in me- 


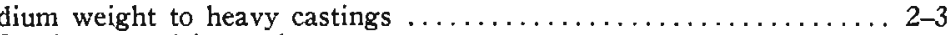

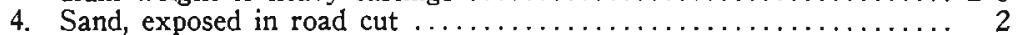

The other location of coarse red sand is found in the southwest quarter of the southwest quarter of section 19, Township 83 North, Range 7 West, just east of Edgewood school No. 1 and also across the

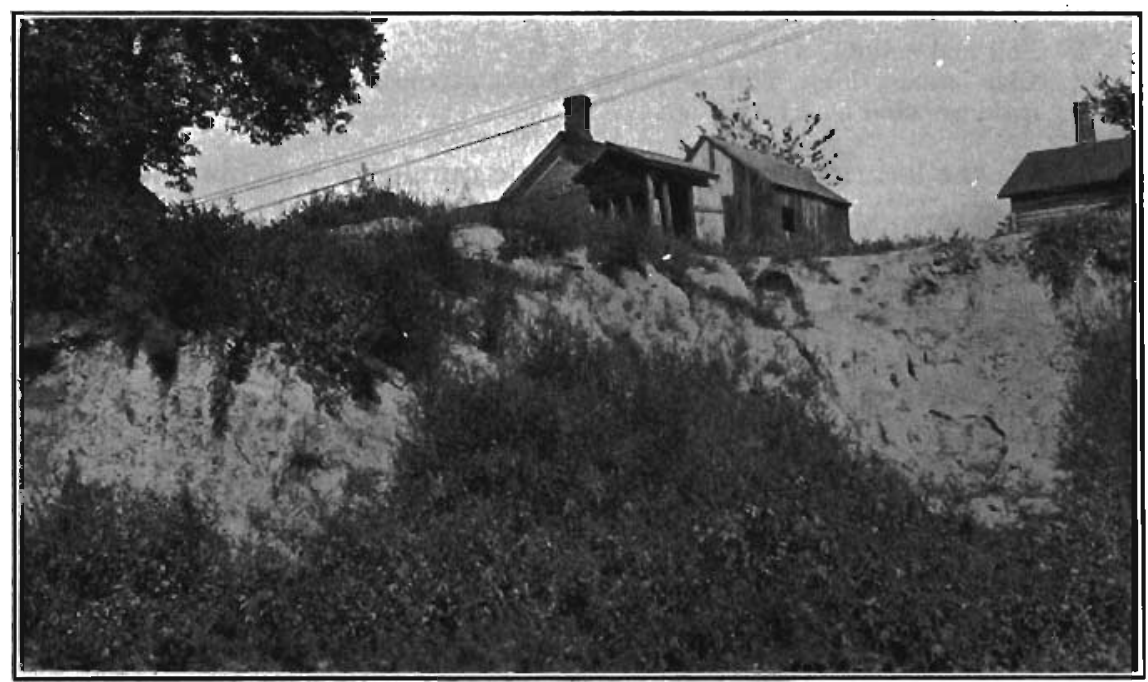

Fic. 72.-The molding sand of sample number seven was taken from this pit on Oak Hill in Cedar Rapids. The molding sand is at left of the weeds and the lower left corner of the cut shows weathered Kansan till. See description on page 468 , and analyses on page 460 .

road westward and northwestward from the school property. It is in a ridge that extends nearly northwest and southeast, and on which ithe Edgewood school is located. The section is very similar to that given for the exposure near Covington. See location on special map p. 468.

Other typical sections on the west tris $_{r}$ side of Cedar river in Linn county Include molding sands having a finer texture than those given above and suited to use in gray iron, brass and aluminum work. One section which may be taken as a type is found in the southeast quarter of the southwest quarter of section 24, Township 83 North, Range 8 West, in the Red Ball road cut on the farm of $f^{\prime}$. Beemer.

Section on L, Beemer's Farm FeET

1. Soil and subsoil $\ldots \ldots \ldots \ldots \ldots \ldots \ldots \ldots \ldots \ldots \ldots \ldots \ldots \ldots \ldots \ldots \ldots \ldots, 2-3$

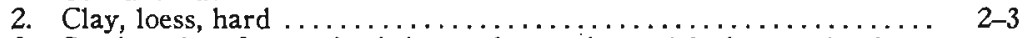

3. Sand, rather fine-grained, loess, the grade used in brass, aluminum and light gray iron work, yellow to brown, noncalcareous through-

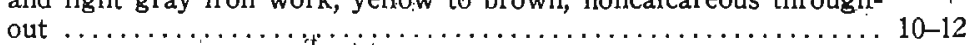

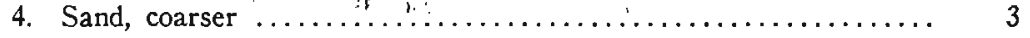


This deposit, like a similar one across the road south of it on the Weaver estate, is several acres in extent. Several sections very much like the one on the Beemer farm are found southward on the west side of the river within five miles of the city, and several others within the city limits.

Section at Oak Hill

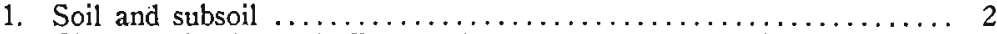

2. Clay, sandy, loess, buff to yellow, noncalcareous, a good grade of molding sand $\ldots \ldots \ldots \ldots \ldots \ldots \ldots \ldots \ldots \ldots \ldots \ldots \ldots \ldots \ldots \ldots, 10$

This is the location from which sample number 7 was obtained. The property is owned and the sand has been used by the Iowa Steel and

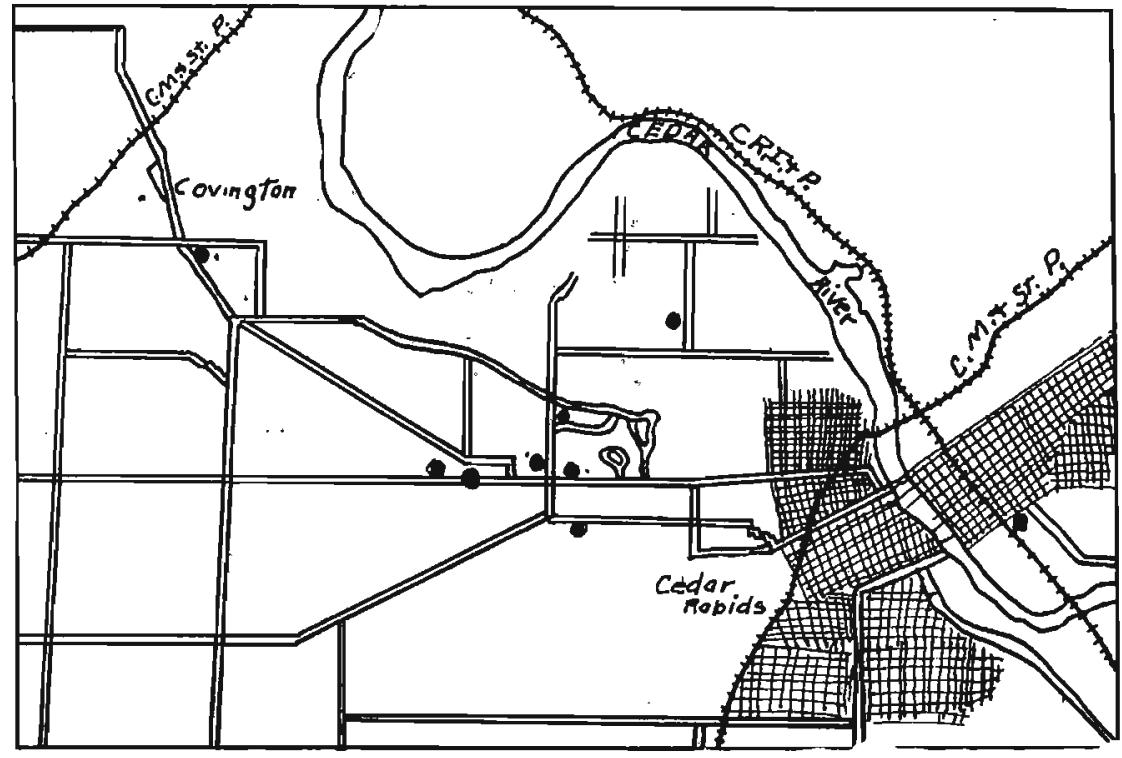

FIG. 73.-The black square shows the location of the Oak Hill pit. Black circles indicate toundry sand

Iron Works. It is an eolian deposit on the leeward side of a small knob of Kansan glacial till, the top of which is seen in the alley at the rear of the property. Sand from this pit was first used by the Dearborn Brass Works of Cedar Rapids to displace sand shipped from Albany, N. Y.

Lonisa County:-A typical deposit is found about two miles east of Fredonia, just east of the middle of section 22, Concord township, in a road cut on the "Great White Way". On the south side of the road, 
the property is owned by $\mathrm{E}$. S. Curtis and on the north side by Mrs. Mary D. Newell, both of Columbus Junction.

Section $\quad$ FEET

1. Soil and subsoil $\ldots \ldots \ldots \ldots \ldots \ldots \ldots \ldots \ldots \ldots \ldots \ldots \ldots \ldots, 3-5$

2. Sand, molding, loessial material, chiefly of the type used in bench

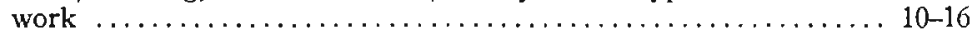

There are doubtless other areas along the east side of this ancient lake that contain molding sand, most of which lies hidden at a depth of several feet. This material has the appearance of having been blow from the west or northwest to its present hillside and hilltop positions.

Marshall County.-Sample number 2 was taken from the pit owned by Lester Williams and located about four miles east of Marshalltown in the northeast quarter of the southwest quarter of section 28, (Marion) Township 84 North, Range 17 West. This pit is located about one-fourth of a mile from the Chicago Great Western railroad. The pit is near the top of a hill and the highway leads directly to the railway crossing near the foot of the hill.

Section $\quad$ in field of clover ......................... ${ }_{1}^{\text {FET }}$

2. Loess, molding sand, buff, with "Kindchen", calcareous throughout,

texture fine to medium $\ldots \ldots \ldots \ldots \ldots \ldots \ldots \ldots \ldots \ldots \ldots \ldots, 8-10$

Pit on the Corey Moore Farm

This pit is on the east bluff of Timber creek on the farm of Corey B. Moore near Rockland quarry in the southwest quarter of the northeast quarter of section 17, (Le Grand) Township 83 North, Range 17 West. This pit is worked by J. O. Winebrenner of Marshalltown. The product is a fine to medium-grained molding sand and is used by foundries in Marshalltown.

Core sand is produced for local use at the pit of the Walter H. Prier Company near their plant two blocks north of the Fair Grounds in Marshalltown.

Section in the Prier Pit FEET

1. Soil and subsoil .................................. $2-4$

2. Sand, with several 1 to 2 inch seams of brownish clay $\ldots \ldots \ldots \ldots \ldots . . . . .2-3$

3. Sand, finer in texture and cleaner, exposed .................... 3

Sample number 1 was taken from numbers 2 and 3 in this pit. The position, extent and structure within the pit indicate that it is a dune ridge whose sand probably had its origin in a flood-plain deposit.

Montgomery County.--An exposure of naterial said by experienced 
foundrymen to be an excellent molding sand occurs in the bluff beside the railroad about a mile southwest of Red Oak on the farm of Anton Neuman in the southeast quarter of the northwest quarter of section 32, Township 71 North, Range 38 West.

The section here shows about ten feet of sandstone very poorly consolidated and having in its upper part several layers or bands of limonite from one-half inch to two inches thick. Above this in the section is two and one-half to three feet of conglomerate which in turn is covered by several feet of glacial till in the slope of the hill. The molding sand lies below the limonite layers, which are several inches apart. The overburden is so thick that this material has not been used for several years. If the overburden or part of it could be used for road material, it and the molding sand might again become an economic possibility.

Muscatine County (See map p. 474).-A pit which has been producing for ten years or more is located opposite the Heinz Manufacturing Company's plant in a northern suburb of Muscatine within 100 yards of the electric railway. This property was in charge of $E$. O. Burnside in 1925.

Section of $P$ it FEET

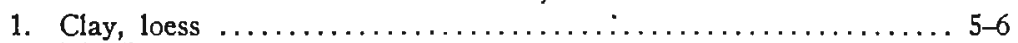

2. Molding sand, contains alternating seams of coarser and finer textures but makes a good average .............................. $5-8$

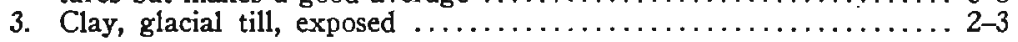

The extent of this deposit is unknown but it seems to include several acres. Probably it decreases in thickness, giving way to loess toward the top of the hill.

Good molding sand is found also in several narrow eolian ridges which cross the "Great White Way" north of the middle of section 34, Township 76 North, Range 3 West. Most of this is in the northwest quarter of the section and lies on the upland about eight miles west of Muscatine. These ridges vary from 100 yards to a quarter of a mile in length and contain molding sand one.to three feet thick under two to three feet of soil.

Good core sand of eolian origin but probably not of commercial importance was found in the southwest quarter of the southwest quarter of section 29, Township 78 North, Range 1 East, and in a roadside cut near the middle of the north line of the northeast quarter of section 2. Township 77 North, Range 1 West. Good red core sand is found 
about one and 'one-half miles east of Muscatine in a bank on the side of the River road in the northeast quarter of the southwest quarter of section 30, Township 77 North, Range 1 West, and also on the west side of section 28 where the same road enters the section about three miles east of Muscatine.

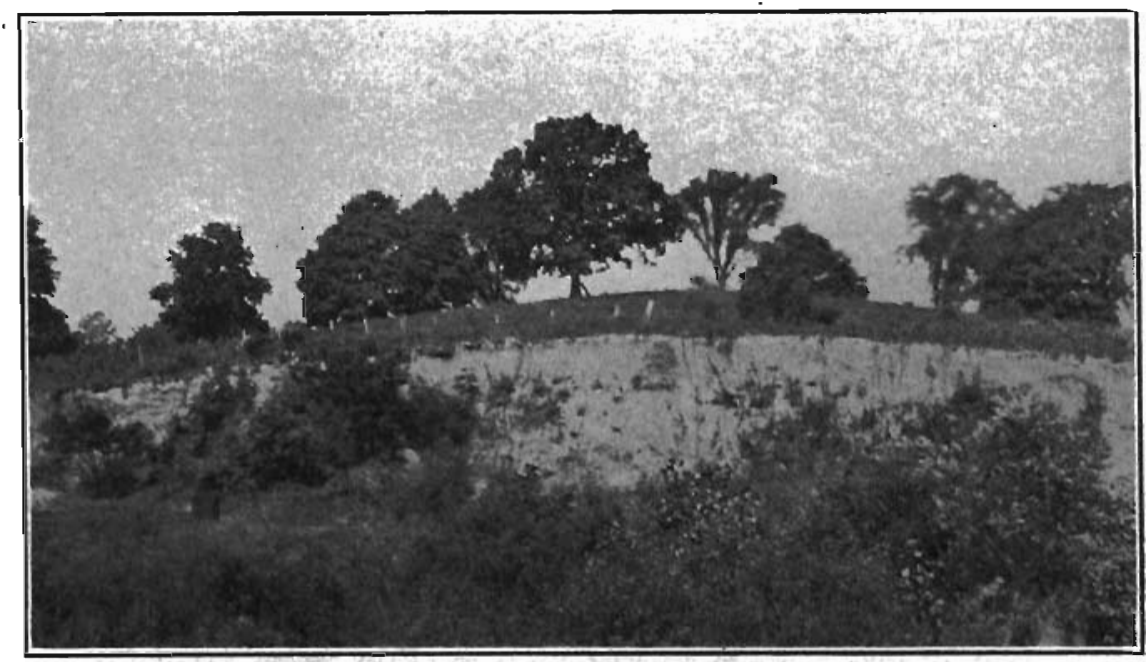

Fıg. 74-A view in the pit at Muscatine from which sample number 11 was taken. See page 470.

A good sand used in the blast for cleaning castings is produced by screening alluvial sand at the plant of the Northern Gravel Company.

Polk County.-The only producing pit in Polk county is the Leon Harris pit in Saylor township, in the northwest quarter of the northeast quarter of section 22, Township 79 North, Range 24 West: This property lies along the Interurban tracks north of Highland Park near the paved road. It is also near the Saylor Center school. Several grades of sand may be obtained from this pit, ranging from fine to coarse-textured material.

Section FEET

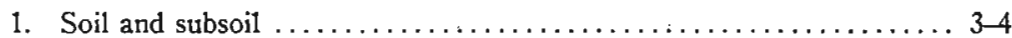

2. Sand, molding, with 2 -inch layers of coarser sand ............. $3-4$

Sample number 8 was taken from number 2 of this section. The deposit apparently extends for some distance to the west and to the north. See figure 75 . 
Several deposits of good molding sand were exposed at the time this survey was made along banks and vacant lots on north Sixth Avenue and one at Shawnee Avenue. These will decrease in availability as

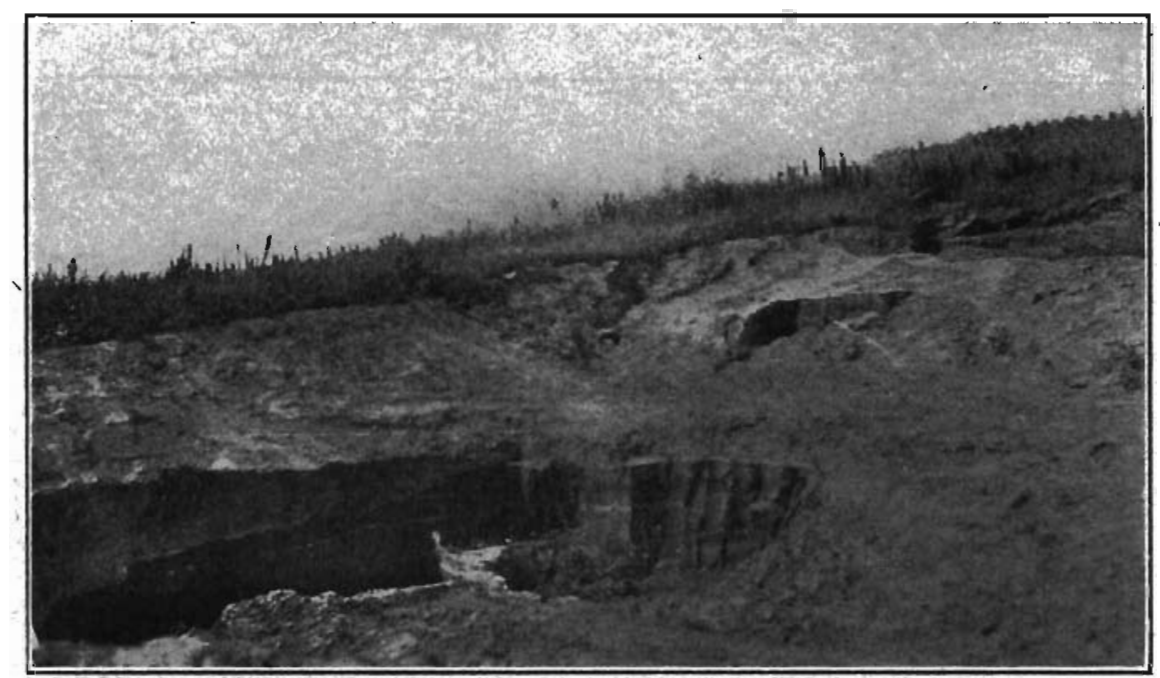

FIG. 75.-A view in the Harris pit at Des Moines showing three openings, each of which produces a molding sand slightly different from the others. Sample number eight was obtained from the large pit in the foreground. See page 460 .

this suburb develops. A layer of rather coarse molding sand about one foot thick was found on the property of the Flint Brick Company near the top of the bluff. Most of this is in the east half of the southeast quarter of section 24 of Saylor township.

These deposits seem to be eolian in character and in topographic position. They lie along the slope and near the top of a rise which is southeast of the broad, flat flood plain of Des Moines river where the present valley crosses the ancient valley of its predecessor. This alluvial plain probably is the source of the wind-blown sand.

Scott County.--One-fourth of a mile south of Dixon in the road cut is an exposure of good molding sand 10 to 12 feet thick under a cover of soil and subsoil three to five feet thick. This occurs in the form of a narrow ridge of loess half a mile long extending nearly northwest and southeast. Thousands of tons of molding sand are available here at a distance of less than half a mile from the railroads (C., M., St. P. \& P., and the C., R. I. \& P.). It is yellow to brown 
in color and is of the type of sand used in aluminum and light gray iron work. It is eolian in origin.

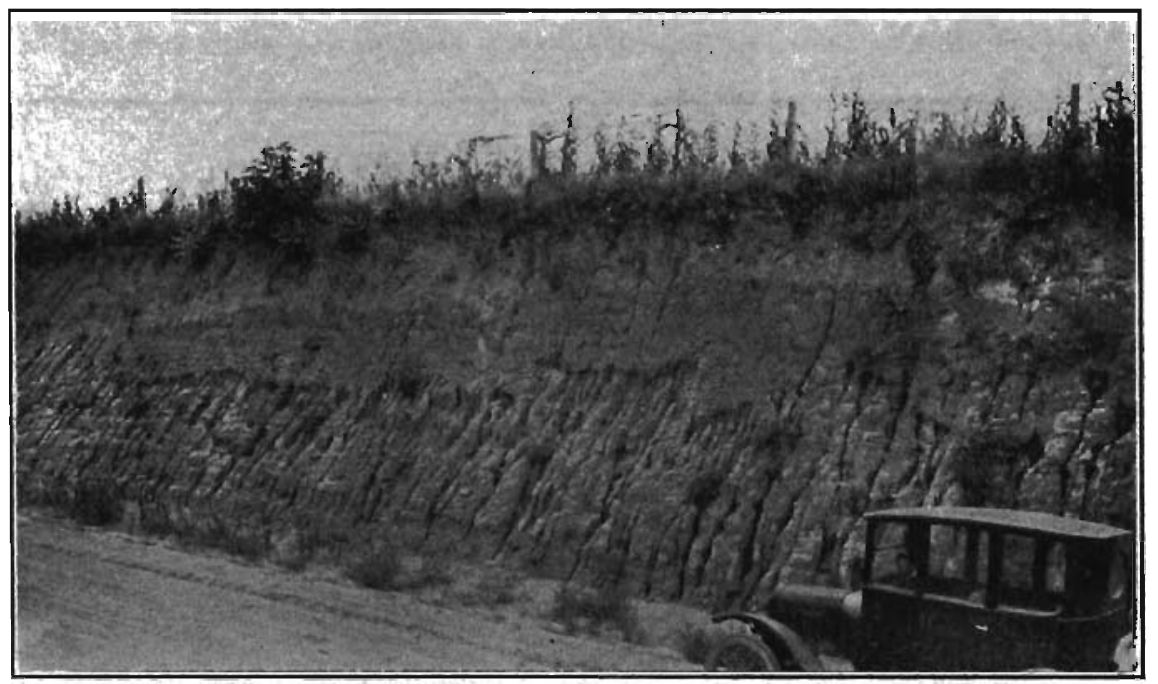

Fic. 76.-The first twelve feet upward from the bottom of the road cut shown here is good molding sand. This is located near Dixon, Scott county, as shown on the map on page 474

At Donahue two good exposures of molding sand were found about a mile north of the railway station: one a few yards east of the crossroads and one about 300 yards north of the intersection. The sands here are coarser than at other places described for this county.

A bank of loess at the roadside one and three-fourths miles east of Long Grove stands 25 feet high under cover of five feet of soil and subsoil. It has the right texture for molding sand for light bench work and is located within half a mile of the paved highway between DeWitt and Davenport. An abundance of this sand is in evidence.

A few other places in the county could produce molding sand but have no commercial value for this purpose at present. See map, fig. 77.

Tama County.-Molding sand of good grade and thickness is found on the south and east sides of the highway intersection east of Montour in the northwest quarter of the southwest quarter of section 26, Township 83 North, Range 16 West, on Lincoln Highway. Here as in several other places more than one grade of sand can be obtained.

\section{Section East of Montour}

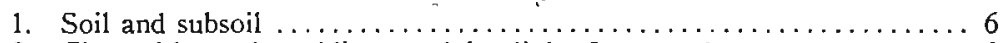

2. Clay with sand, molding sand for light floor work $\ldots \ldots \ldots \ldots \ldots \ldots, 3$

3. Clay with fine sand, for use in brass and aluminum castings $\ldots \ldots \ldots, 5$ 
Several exposures of good molding sand are found in the road cuts along Lincoln Highway on the north side of the Iowa river valley in the eastern part of the county with Chelsea as the nearest central point. A corresponding series of deposits occurs also on the south side and on

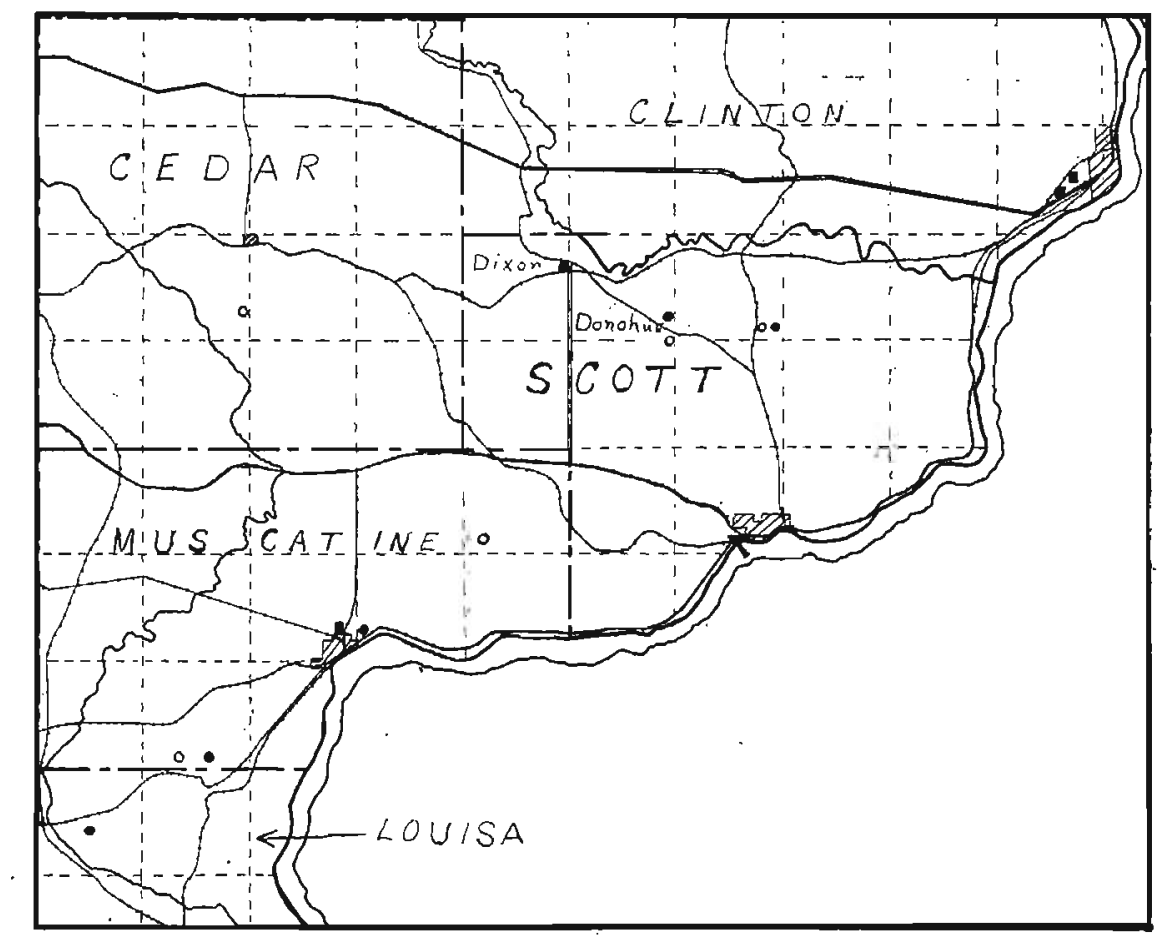

FIG. 77.-Pits producing molding sand are shown in shaded squares. Areas believed to be possible commercial producers are shown in black circles. The black circle just east of Muscatine indicates location of red core sand. Open circles indicate unimportant localities.

the south bluff of the valley chiefly in (Richland) Township 82 North, Range 14 West. None of these deposits has been exploited.

About two miles east of Tama on Lincoln Highway in the road cut at the Summit farm, the following section was seen.

\section{Section East of Tama}

FEET

1. Soil and subsoil

2. Clay mixed with sand, a good molding sand for light work

At several other places both east and west of Tama openings could be developed as producing pits of molding sand.

Wapello County.-The foundry sand production of Wapello consists chiefly of material that is used as core sand. This may be classed 
as river sand, "bank sand" and bluff sand. The first of these is alluvial; the second, chiefly eolian; the third is probably eolian and residual.

Eddyville.-The "yellow bank sand" half a mile east of Eddyville is obtained from a pit in an area decidedly eolian in character. This area is located at the top and on the upper slope of the valley wall along the eastern boundary of the northeast quarter of section 6 , Township 73 North, Range. 15 West.

On the farm of the owner of this property, Mr. S. L. Lemmon, a ridge has been formed by drifting sand along an old fence row and in this ridge, Mr. Lemmon reports, two fences have been buried deeply enough to require that new fences be built.

Ottumwa.-Sample number 10 was taken from the Henry.J. Franklin pit, see figure 78, at the upper end of Randolph Street and near the middle of the boundary line between sections 13 and 14, Township 72 North, Range 14 West.

Section in the Franklin Pit FEET

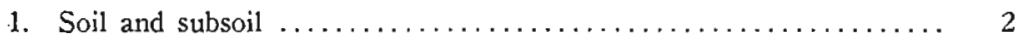

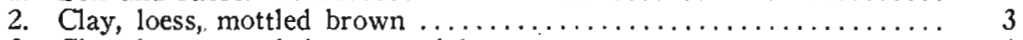

3. Clay, loess, mottled gray and browh ................... 4

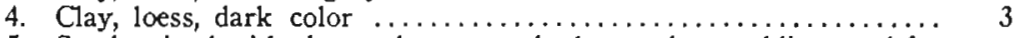

5. Sand, mixed with clay, red, core sand, also used as molding sand for extra heavy castings ............................. 6-10

6. Sand, red, finer in texture than number five above; to bottom of pit $3-5$

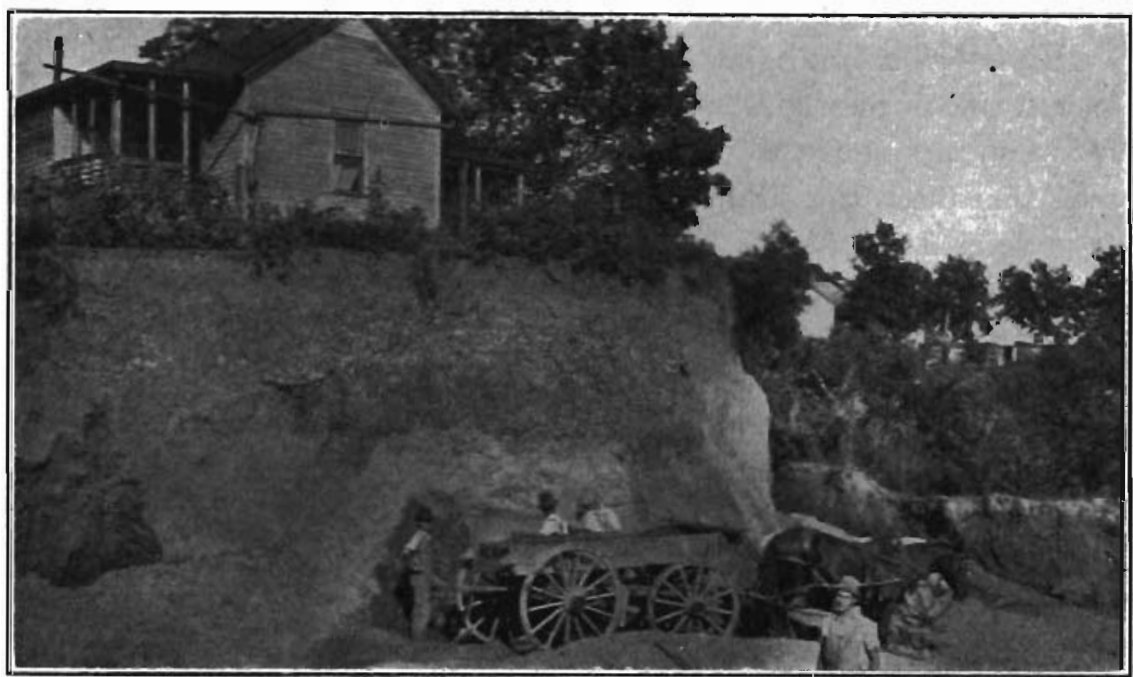

FrG. 78.-A view in the Franklin pit at Ottumwa where sample number 10 was obtained. This shows the methods employed in exploitation. See page 460 
Sand is taken from numbers 5 and 6 of this section and loaded into box cars about one mile from the pit, see figures 78 and 79 .

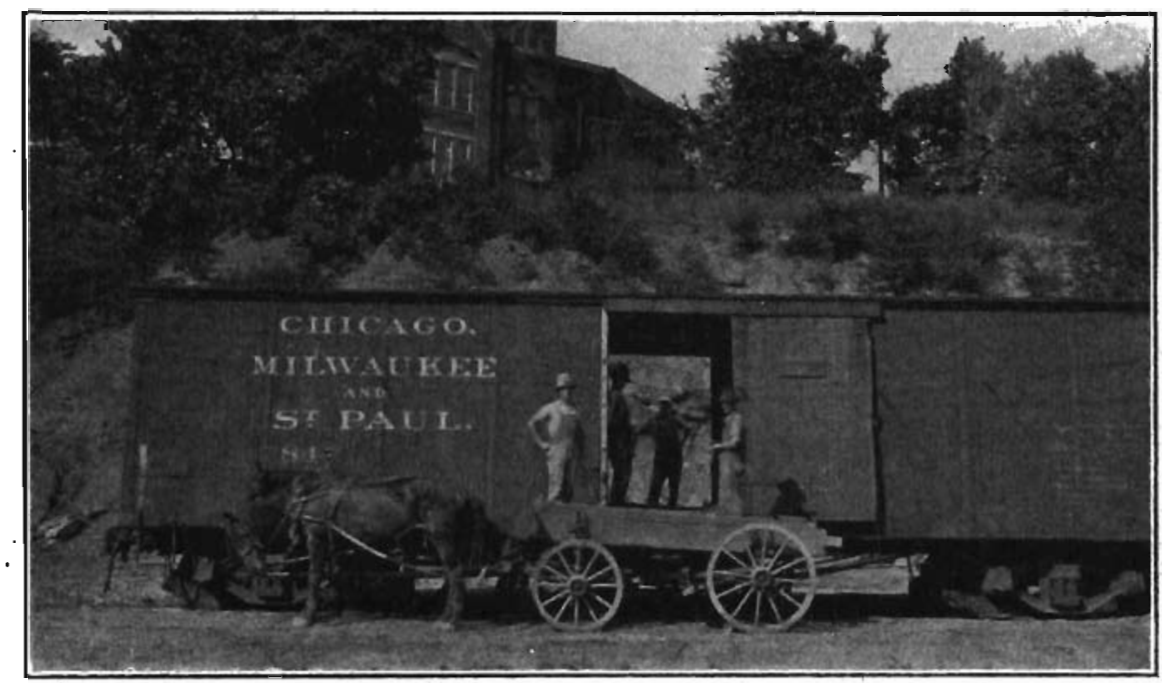

Fic. 79.-The method of loading cars at Ottumwa with molding sand from the Franklin pit, Ottumwa, is shown here.

Similar sand is found in a pit opened at the foot of the hill, half a mile south of the Franklin pit, along the creek opposite the base ball park, and also on both sides of South Walnut Street near South Main Street.

Origin.-The position of this material above the Kansan till and on east side of the valley suggests that it is eolian sand covered by loess. It is noncalcareous throughout and this with its deep red color indicates that the entire section given above has been subjected to intense or prolonged weathering. It is therefore believed to be a natural mixture of glacial, eolian and residual material.

This sand is used extensively by the Holland Furnace Company at Cedar Rapids.

\section{Geology}

Foundry sand or molding sand as it is more commonly called is a mixture of several sizes of sand with clay and water. The proportions of each size of sand differ considerably as may be seen from the table of analyses given on page 460. The clay commonly ranges from five per cent to thirty per cent and the water from three to eight per cent, with a few extremes exceeding these limits. It must be coarse 
enough to permit the gases from the molten metal as it cools to pass through between the grains easily and yet without causing movement among them. For use in making small screws, small lock keys, and other small objects of brass and aluminum, a very fine sand is necessary and loess is commonly employed for this purpose, also for some of the larger and heavier work, but for much of the latter a coarser sand must be provided. Natural mixtures of these substances, are commonly used except for special kinds of work and for steel casting. For these artificial mixtures are prepared.

Few of the deposits of molding sand studied seem to be the result of a single geological process. Most of them are found to have originated from the work of several agencies, one of which, the wind, is chiefly dominant. Some of the terrace deposits, that west of Madrid in Boone county for example, are strictly alluvial, having been formed as flood-plain deposits at a time when the river valley was not so deep as at present and then covered to a depth of several feet before a part of the valley boțtom was cut down to its present level.

On wide flood plains the wind seems to have moved much of the finer material and some of the coarser, depositing it in ridges or other forms of drift on the flood plain. Most of these dune ridges extend in a direction approximately northwest and southeast. Good examples of this type are found at Marshalltown and on the Mississippi terraces southwest of Fort Madison.

Some of the alluvial deposits of the flood plains have been swept by high winds during the dry seasons to the borders of the valleys and even to the slopes and bluffs beyond, forming deposits of sand and loess. These deposits are almost invariably east and southeast of the source of the material in them, which position indicates northwest to west winds during the time of deposition of each. Deposits of this type located on the top of the bluffs are well illustrated in Marshall and Jasper counties. Pits located on the slope are found on the east side of the river at Cedar Rapids, in the city of Clinton, in the Highland Park section of Des Moines and in the northern suburbs of Ottumwa.

Some of the larger river valleys, such as the Iowa in Muscatine and Louisa counties and perhaps others, may have served as lake basins during the time that glacial ice formed dams âcross them. If so, the deposits blown from the bottoms of such river valleys are partly lacustrine in their origin. 
Glacio-fluvial.-When glacial ice is melting the resulting water brings to its margin large quantities of clay, rock flour, fine sand, coarser sand and gravel. These materials are sorted by the water and in some places the sands and clays are mixed in the right proportions to serve as molding sands. It is obvious that such mixtures will be. small and irregular in extent. The best examples of this type seen are in Dallas county east of Redfield and in Benton county north of Shellsburg.

Glacio-eolian.-On the uplands along the margins of the Iowan and Illinoian glacial deposits there are mounds, ridges and dunes of mixtures of sand and clay in various proportions. These materials, like most of the molding sands, are found southeastward from their sources. While the molding sand in these deposits-is somewhat irregular in thickness and extent, it is also found to be among those sands that rank highest in quality.

Materials of this origin are derived from marginal glacial deposits by eolian extraction, transportation and deposition. Examples of this type are found in Fayette, Bremer, Johnson and Muscatine counties.

Eolian and residual.-In nearly all deposits that yield foundry sand weathering has played an important part as to origin, especially near the surface. It is only in the older Pleistocene deposits that weathering can reach its maximum influence working alone. When a large area of much weathered material is subjected to transportation by the wind it may be formed into hills and ridges composed of weathered material throughout.

Given sufficient time a deposit may weather and leach deeply. In a favorable position, as near the brink of a valley bluff in a region of higher and lower precipitation and water table, weathering takes place more rapidly than elsewhere in the vicinity and considerable depths of oxidation may be reached much more quickly than in the other topographic positions. The deposits at Ottumwa are intensely weathered but it is not entirely clear how this intense and deep oxidation was accomplished.

\section{Reasons for "Importations"}

Lack of Knowledge.-Iowa molding sarids are little known. Few who own land of potential production can recognize molding sand when they see it and most of them do not even know that they have such a 
thing on their property. Many of these owners when this identification of material is made for them are doubtful about its commercial value or are financially unable to undertake its development or are afraid to do so. Though foundrymen want to buy sand from someone who makes a business of selling it, some of them have been forced to buy a pit or to lease one and operate it in order to obtain a reliable grade of material. The exploitation of molding sand, like that of any other kind of material, should be conducted by responsible people.

The business of marketing molding sand in many places is conducted by teamsters or truckmen who engage in it for the purpose of obtaining employment by hauling. They do not.know molding sand either and some of them are very careless in loading it. They will put into the load clay or other material that is easy to obtain and thereby reduce the quality of the sand or possibly destroy its value entirely.

The sand occurs in zones or layers below the soil and subsoil, which is commonly two to three feet thick. Beneath this soil the zone of molding sand may be only one or two feet thick but in most localities a thickness of five to ten feet may be found. In several places a thickness of 15 to 20 feet exists.

It is therefore necessary for those who work in the sand pits to know thoroughly the material they are putting on the market and to use great care in doing so. In several counties in Iowa pits that would yield good molding sand have lost customers through carelessness in loading when filling orders.

Lack of Experiment.-Because of lack of experiment a full knowledge of the practical uses and adaptations of Iowa foundry sands is not available for distribution to those who may be able to save money by using Iowa's natural product. Some experimental work might be profitably carried on by the various foundries of the state and some by engineering experiment stations.

Lack of Desire.- Some of the men who are employed as molders in Iowa foundries were formerly engaged in the same work in eastern states and insist that they be provided with the same sand that they used there. This insistence brings much eastern sand into Iowa every year. That Iowa sand is equal in value or superior to the eastern sand is shown by the experience of the Dearborn Brass Works at Cedar Rapids where sand from a well-known locality of New York (Albany) 
was replaced by Iowa sand more than five years ago at the request of the superintendent in charge and has been used exclusively ever since.

\section{Prepared Sand}

Nearly all of the larger foundries and most of the smaller ones use in molding some sand that has been mixed in somewhat definite proportions. In steel casting a clean sand and a pure clay are used.

Most of the core sand used in gray iron work is artificially mixed with clay after being carefully screened. Of the mixed sand used in Iowa, however, the greater part is made by combining portions of natural molding sand from two or more localities. It is a common conception that any sand whose cost is high is a good one and that it will improve the quality of any sand with which it may be mixed.

Partly for this reason sand from Albany (New York) enjoys a large sale in Iowa. This is also true of some of the sand shipped here from Illinois and Ohio.

Some firms arẻ now offering for sale molding sand prepared for use in each of the respective classes of foundry work. Such sand is finding increasing sale in Iowa, especially among the larger foundries, whose work is chiefly that of filling orders obtained by contract in which the manufacturer is to meet specifications requiring carefully standardized work.

\section{Summary and Conclusions}

Molding sand is found on and near the bluffs east and southeast of the larger stream valleys or of large curves in these valleys. It is found also on the upland in interstream areas in Beriton, Cedar and a few other counties. It occurs chiefly in deposits believed to be eolian and some of these are in the form of ancient dunes now covered with soil. Part of the molding sand in some of these old dunes is a residual mixture.

In many places the deposits consist of thin layers of argillaceous sand alternating with thin layers of silt or clay in such quantities as to give the right proportions of these ingredients for molding sand. The grains of sand are coated with iron oxide. which gives them a color varying from red to buff. In many places this coloring of the sand grains is somewhat uniform through a depth of five to twenty-five feet in the deposit. These deposits are believed to have been accumulated by action of the wind. When wind velocity was high the layers of 
coarser material were transported and this gave way to deposits of silts and clays when the wind velocity was low. Much of the coloring was done probably before the material was transported to its present position. Some of the smaller deposits of molding sand may be partly fluvial in origin.

There is an abundance of nearly all kinds of molding sand in Iowa and some of each is now being used in the various foundries of the state. The principal producing counties are Polk, Jasper, Marshall, Cedar, Floyd, Johnson, Muscatine and Wapello. Our own sand should be used much more extensively instead of that shipped here from other states.

\section{Consumers of Molding Sand}

Boone.-Boone Foundry and Machine Works; Quinn Wire and Iron Works

Burlington.-Murray Iron Works

Cedar Rapids.-Cedar Rapids Foundry and Machine Co.; Chandler Pump Co.; Dearborn Brass Works; Foster Brass Works; Holland Furnace Co. ; Starry Foundry Co. ; Universal Foundry Co. ; Iowa Steel and Iron Works

Charles City.-Hart-Parr Company

Clarinda.-Lisle Manufacturing Company

Clinton.-Climax Engineering Co.; Clinton Lock Co., Lyons; Iowa Machine Works

Council Bluffs.-Griffin Wheel Co.; Kimball Bros. Co.

Davenport.-American Sash Weight Foundry; Black Hawk Foundry Co.; Davenport Locomotive Works, Davenport Machinery and Foundry Co.; Frank Foundry and Machine Co.; French and Hecht Manufacturing Co.; The Red Jacket Company

Des Moines.-Des Moines Foundry and Machine Co.; Eagle Iron Works; Green Furnace Company; Keith Furnace Company; New Monarch Foundry; Wood Bros. Thresher Company

Dubuque.-The Adams Company; Key City Iron Works; Klauer Manufacturing Company; A. Y. McDonald Manufacturing Company; The Smedley Company

Fairfeld.-Dexter Washing Machine Company; Iowa Malleable Iron Company

Fort Madison.-Cushman Machine Works

Iowa City.-Iowa City Iron Works 
Marshalltown.-Central Foundry Co. ; Lennox Furnace Co. ; Victor Furnace Co.; Walter H. Prier Company (brass)

Muscatine.-Muscatine Boiler and Sheet Iron Works; Niver Iron Works

Newton.-Maytag Manufacturing Company; Newton Foundry Company

Oskaloosa.-Ideal Manufacturing Company; Iowa Valve Company

Ottumwa.-Hardsoeg Manufacturing Company; Ottumwa Iron Works

Perry.-Progressive Foundry

Red Oak.-Kerrihard Company

Sioux City.--Iowa Foundry Company; Sioux City Foundry and Boiler Company

Waterloo.-Hawkeye Foundry Company; Headford Bros. and Hitchins Foundry Company; Swift Manufacturing Company; Waterloo Gasóline Engine Company

\section{CONSUMERS OF WHITE SILICA CORE SAND}

Bettendorf.-Zimmerman Steel Company

Fairfield.-Iowa Malleable Iron Company

Keokuk.-Keokuk Steel Casting Company

Waterloo.-Hawkeye Foundry Company

\section{SOURCES OF FOUNDRY SAND USED IN IOWA}

Molding Sand.-Iowa Steel and Iron Works, Cedar Rapids; HartParr Company, Charles City; F. A. Chinn, Harrison Road, Clinton; N. Leon Harris, Box 507, Des Moines; Iowa City Iron Works, Iowa City; Lester Williams, 8th St., at Fairgrounds, Marshalltown; J. C. Winebrenner, 904 E. Main, Marshalltown; E. C. Burnside, 306 E. Second St., Muscatine; Ben Lufkin, Reasnor, Jasper county

Core Sand.-C. W. Messer, 534 10th Ave., Clinton; Eddyville Coal Company, Eddyville; Walter H. Prier, Marshalltown; Ottumwa Sand Company, Ottumwa; Iowa Foundry Sand Company, Waterloo.

Silica Sand (For steel molding).-Langworthy Sand Company, Clayton

Blast Sand (For cleaning castings).-Northern Gravel Company, Muscatine

Molding Sand.--Illinois. Akin, Batavia, Collinsville, Dallas City, 
East Dubuque, Elgin, Galena, Gladstone, Granite City, Milan, Moline, Ottawa, Warren, Wilbur, Wyanet

Indiana. Michigan City

Kansas. Atchison

Michigan. Locality not known

Minnesota. Ottawa

Missouri. Kansas City

Nebraska. Endicott

New York. Albany

Ohio. Conneaut, Sandusky

South Dakota. Sioux Falls

Wisconsin. Beloit, Burlington 



\section{INDEX}

A

Albany, New York, molding sand from, 480 ; tests of sand from, 459

Alluvial deposits used as molding sand, 477

Aluminum, molding sand for, 467

\section{B}

Benton county, molding sand in, 458; origin; 478

Bettendorf, core sand used in, 482

Black Hawk county, molding sand in, 458

Blast sand, sources, 482

Boone, molding sand used in, 481

Boone county, molding sand in, 458

Brass, molding sand for, 467

Bremer county, molding sand in, 459; origin, 478

Burlington, molding sand near, 462 ; used in, 481

\section{C}

Cedar county, molding sand in, 459 , 481

Cedar Rapids, molding sand in, 467, 482; origin, 477; tests, 459 ; use, 479 , 481

Charles City, molding sand used in, 481

Chelsea, molding sand near, 474

Clarinda, molding sand used in, 481

Clay in molding sand; 457

Clayton, silica sand from, 462,482

Clayton county, molding sand in, 462

Clinton, core sand from, 482; molding sand at, 462, 482; origin, 477; tests, 459 ; used in, 481

Clinton county, molding sand in, 462 ; tests, 459

Columbus Junction, molding sand near, 469

Core sand in Linn county, 466; in Marshall county, 469; in Muscatine county, 470; in Wapello county, 474; sources, 482 ; use, 480

Covington; molding sand near, 466
Dallas City, Ill., tests of sand from, 459

Dallas county, molding sand in, 462; origin, 478

Davenport, molding sand near, 473; used in, 481

Dixon, molding sand near, 472

Des Moines, molding sand in, 471, 482; origin, 477 ; tests, 459 ; used in, 481

Des Moines county, molding sand in, 462

De Witt, molding sand near, 473

Donahue, molding sand near, 473

Dubuque, molding sand used in, 481 .

Dubuque county, molding sand in, 463

Dune sand used as molding sand, 469

\section{E}

Eddyville, core sand from, 482 ; molding sand near, 475

Eolian deposits used as molding sand, $465,470,472,478$; used as welding sand, 468

\section{F}

Fairfield, core sand used in, 482; molding sand used in, 481

Fayette county, molding sand in, origin, 478

Floyd county, molding sand in, 463 , 481 ; tests, 459

Floyd Station, tests of sand from, 459

Fort Madison, molding sand in, 466; origin, 477 ; used in, 481

Foundry sand used in Iowa, geology, 476; sources, 482 ; tests on, 457 ; see molding sand

Fredonia, molding sand near, 468

\section{G}

Geology of molding sand, 476

Glacio-fluvial materials used as molding sand, 478

\section{I}

Illinois, molding sand from, 480, 482; tests of sand from, 459 
Indiana, molding sand from, 483

Iowa City, molding sand from, 482; tests, 459; used in, 481

Iowa county, molding sand in, 463

Iowan ice sheet, molding sand near, 465

Iron, gray, molding sand for, 467

\section{J}

Jasper county, molding sand in, 464, 481 ; origin, 477 ; tests, 459

Johnson countỹ, molding sand in, 464 , 481 ; origin, 477 ; tests, 459

\section{$\mathbf{K}$}

Kansan glacial till, molding sand in, 468

Kansas, molding sand from, 483

Keokuk, core sand used in, 482

\section{$I$}

La Porte City, molding sand near, 458

Lee county, molding sand in; 466

Linn county, molding sand. in, 466; tests, 459

Littlefield, M. S., work on molding sands, 458

Loess used as molding sand, 477

Long Grove, molding sand near, 473

Louisa county, molding sand in, 468

\section{$\mathbf{M}$}

Madrid, molding sand near, 458 ; origin, 477

Marble Rock, molding sand near, 463

Marshall county, molding sand in, 469, 481 ; origin, 477 ; tests, 459

Marshalltown, core sand from, 482; molding sand near, 469, 482; origin, 477; tests, 459 ; used in, 482

Mechanicsville, molding sand near, 459 Michigan, molding sand from, 483

Midriver, molding sand near, 465

Milan, Illinois, tests of sand from, 459

. Minnesota, molding sand from, 483

Missouri, molding sand from, 483
Molding sand, character, 480; composition, 457; geology, 476; Iowa, description, 458; in Benton county, 458 ; in Black Hawk county, 458; in Boone county, 458; in Bremer county, 459; in Cedar county, 459; in Clayton county, 462 ; in Clinton county, 462; in Dallas county, 462; in Des Moines county, 462; in Dubuque county, 463; in Floyd county, 463; in Iowa county, 463; in Jasper county, 464; in Johnson county, 464; in Lee county, 466; in Linn county, 466; in Louisa county, 468; in Marshall county, 469; in Montgomery county, 469; in Muscatine county, 470; in Polk county, 471; in Scott county, 472; in Tama county, 473; in Wapello county, 474; lack of desire to use, 479; lack of experiment with, 479; lack of knowledge of, 478 ; method of occurrence, 477-480; origin, 458, 465, $468,472,475,476,480$; permeability, 457; prepared, 480; reasons for importations, 478; sources, 482 ; tests, 460 ; types, 475,478

Montgomery county, molding sand in, 469

Montour, molding sand near, 473

Muscatine, blast sand from, 482 ; molding sand near, 470; tests, 459; used in, 482

Muscatine county, molding sand in, 470, 481; origin, 478; tests, 459

\section{$\mathbf{N}$}

Nebraska, molding sand from, 483

Newton, molding sand used in, 482

New York, molding sand from, 483; tests, 459

Nora Springs, tests of sand from, 459

Ohio, molding sand from, 480, 483

Oskaloosa, molding sand used in, 482

Ottawa, Illinois, molding sand at, 462 .

Ottumwa, core sand from, 482; molding sand near, 475 ; origin, 477,478 ; tests, 459 ; used in, 482 
$\mathbf{P}$

Permeability of molding sand, 457

Perry, molding sand used in, 482

Polk county, molding sand in, 471, 481; tests, 459

\section{$\mathbf{R}$}

Reasnor, molding sand near, 464; tests, 459

Redfield, molding sand near, 462; origin, 478

Red Oak, molding sand near, 470; used in, 482

Residual deposits used as molding sand, 478

Ries, H., work of, on sands, 457

\section{S}

Sandstone used as molding sand, 470 Scott county, molding sand in, 472

Shellsburg, molding sand near, 458
Silica sand, sources, 482

Sioux City, molding sand used in, 482

South Dakota, molding sand from, 483

Stanwood, molding sand near, 459

\section{$\mathrm{T}$}

Tama, molding sand near, 474

Tama county, molding sand in, 473

Tests of molding sands, 460

Tiffin, molding sand near, 465

\section{W}

Wapello county, molding sand in, 474 , 481 ; tests, 459

Waterloo, core sand from, 482; used in, 482; molding sand near, 458, 462; used in, 482

Waverly, molding sand near, 459

Wisconsin, molding sand from, 483

Wisconsin glacial drift, molding sand in, 462 
